\title{
Onderwijs als scheidslijn op de Nederlandse arbeidsmarkt, 1993-2011
}

\author{
Paul M. de Graaf \& Maarten H.J. Wolbers
}

MEM 90 (4): 321-342

DOI: 10.5117/MEM2015.3.GRAA

\begin{abstract}
Summary
Education as a cleavage in the Dutch labour market, 1993-2011

This article describes developments in the association between educational attainment and labour market outcomes in the Netherlands over the last 20 years. Education has remained a very important asset on the labour market. The higher educated have higher participation rates and attain better jobs than the lower educated. The labour market participation rate has increased for all educational categories, and especially for women with low educational qualifications. The association between educational attainment and unemployment has not changed over this period. We do observe that higher credentials have less value on the labour market with respect to occupational status than before, pointing to overschooling. Furthermore, we see that the permanent full-time job is on the downhill. The relationships between educational qualifications and permanent or full-time jobs have not changed systematically over the two decades.
\end{abstract}

Keywords: educational attainment, labour market outcomes, social inequality, overschooling

\section{$1 \quad$ Inleiding en achtergrond}

Van alle scheidslijnen die het onderwijs aanbrengt in onze samenleving, behoren die op de arbeidsmarkt zeker tot de belangrijkste. De kansen die iemand heeft op werk en op een goed betaalde baan zijn sterk gerelateerd aan het opleidingsniveau dat iemand heeft bereikt. Deze conclusie werd in 
1996 getrokken in de WRR-studie over de voorziene sociale segmentatie van Nederland in 2015 (De Graaf, 1996).

Er is een aantal manieren waarop verschillen in opleidingsniveau doorwerken op het succes op de arbeidsmarkt. Bij veel van de keuzes die werkgevers maken, gebruiken ze informatie over het onderwijs dat potentiële werknemers hebben gevolgd. Die keuzes zijn vaak ook afgedwongen, omdat het in een aantal beroepen is voorgeschreven dat men aan bepaalde diploma-eisen moet voldoen (Lutz \& Sengenberger, 1974). Dat geldt ook voor het werk dat zelfstandigen doen. Daarnaast lezen werkgevers aan het diploma af of een potentiële werknemer productief zal zijn. Diploma's zijn belangrijk, omdat ze laten zien dat men bepaalde vaardigheden heeft geleerd die belangrijk zijn voor een beroep (Becker, 1964), en ook, omdat ze tonen dat men over bepaalde, met dat diploma samenhangende, kenmerken beschikt die iemand productief kunnen maken (Spence, 1974). In het onderwijs wordt geselecteerd op kenmerken als intelligentie, doorzettingsvermogen, creativiteit, cultureel kapitaal en sociale herkomst. De baancompetitietheorie zegt dat als werkgevers kunnen kiezen tussen kandidaten, zij dan, ceteris paribus, de voorkeur geven aan de hoogst opgeleide (Thurow, 1975). We merken op dat als het werkgevers puur zou gaan om de op school geleerde vaardigheden, deze theorie niet opgaat. Op een hogere opleiding verwerft men immers niet altijd meer of betere vaardigheden voor een specifiek beroep. Onderzoek heeft echter laten zien dat de snelle onderwijsexpansie er niet toe heeft geleid dat hoger opgeleiden geen werk vonden en dus een steeds hogere kans op werkloosheid hadden (Wolbers, 2011). Hoger opgeleiden vonden werk beneden hun niveau en daardoor werden mensen met middelbare of lagere diploma's gedwongen ook af te zakken. De allerlaagst opgeleiden hebben een grotere kans van de arbeidsmarkt weg te worden geconcurreerd, wat in een laagconjunctuur zeer nadelig kan zijn.

De achtergrond van dit alles is een wedloop tussen technologische vooruitgang en onderwijsexpansie (Tinbergen, 1975; Wolbers, De Graaf \& Ultee, 2001). De geschetste ontwikkeling vindt slechts dan plaats wanneer het tempo waarin eenvoudiger werk wordt vervangen door moeilijker werk lager ligt dan het tempo waarin nieuwe generaties zich hoger scholen. Als het andersom ligt, dan moeten werkgevers genoegen nemen met lager opgeleide werknemers. Waarschijnlijk zal dit niet gauw gebeuren, omdat nieuwe generaties geneigd zullen zijn te investeren in hogere diploma's, omdat dat interessanter en beter betaald werk oplevert. Het ligt daarom voor de hand dat de onderwijsexpansie het wint van de technologische vooruitgang. Overscholing is dan een feit. Op macroniveau is dit een pro- 
bleem, omdat de investeringen in het onderwijs niet resulteren in een productievere beroepsbevolking. Op microniveau leidt overscholing tot minder arbeidssatisfactie onder werkenden.

Economen denken hier over het algemeen anders over (Hartog, 2000; Burris, 2005) en menen dat wanneer hoger opgeleiden terechtkomen in lagere banen dan zij gewend zijn, zij hun hogere productiviteit meebrengen en dus productiever zullen zijn in die andere, aanvankelijk minder individuele capaciteiten vragende banen. De economische hypothese kan worden getoetst door uit te zoeken of binnen een gegeven beroep hoger opgeleiden beter worden beloond dan lager opgeleiden.

In dit artikel gaan we aan de hand van beschrijvende statistieken na in hoeverre de relatie tussen opleiding en arbeidsmarktpositie is veranderd in Nederland gedurende de laatste twintig jaar. In de WRR-studie uit 1996 werden voorspellingen gedaan voor de periode 1995-2015 (de Graaf, 1996). Door ons werd voorspeld dat ook in deze periode de groei van het onderwijs de opwaardering van de vraag naar arbeid zou overtreffen. Jonge cohorten kiezen steeds meer voor hogere opleidingen omdat die de vooruitzichten op gunstige beroepsloopbaan verbeteren. Binnen het, althans voor de onderwijsvolgenden, goedkope Nederlandse onderwijs, werd er geen tegenkracht voorzien. Verder verwachtten we dat de relatie tussen opleiding en werkloosheid zou groeien wanneer er zich ongunstige conjuncturele ontwikkelingen zouden voordoen. Dit was het pessimistische stagnatie CPB-scenario, global shift genoemd, dat werkelijkheid zou worden wanneer globalisering zou leiden tot een gebrek aan concurrentiekracht van de Nederlandse economie (Centraal Planbureau, 1993). De export zou afnemen en de vraag naar arbeid zou dalen met een groeiende werkloosheid als logisch gevolg.

Om deze voorspellingen te toetsen, kijken we naar wat er gebeurd is in de periode 1993-2011. We starten in 1993 omdat dit het jaar is waarin de trend beschreven in de eerdergenoemde WRR-studie uit 1996 ophield. Jammer genoeg is 2011 het laatste jaar dat we kunnen onderzoeken. Er zijn nog geen recentere microdata beschikbaar. We gebruiken de jaarlijks door het Centraal Bureau voor de Statistiek (CBS) gehouden Enquête Beroepsbevolking (EBB), de meest gezaghebbende bron voor informatie over ontwikkelingen op de Nederlandse arbeidsmarkt. Het steekproefkader van de EBB is niet de beroepsbevolking zelf, maar de potentiële beroepsbevolking. Dit is belangrijk, omdat er belangrijke verschillen zijn tussen (a) de potentiële beroepsbevolking, (b) de (actieve) beroepsbevolking en (c) de werkzame beroepsbevolking (Dirven \& Janssen, 2012). De potentiële beroepsbevolking bestaat uit alle $15-64$-jarige Nederlanders, inclusief hen die 
niet actief zijn op de arbeidsmarkt, met name onderwijsvolgenden, huisvrouwen, arbeidsongeschikten en vroegtijdig gepensioneerden. De (actieve) beroepsbevolking beslaat het deel van de bevolking dat óf werkt óf naar werk zoekt. De respons van de EBB is ongeveer 40 à 45 procent wat gebruikelijk is voor Nederlands enquête-onderzoek. Hoewel er opweegfactoren beschikbaar zijn die de data representatief maken voor de hele Nederlandse bevolking, zien we er vanaf deze te gebruiken omdat we veel minder belangstelling hebben voor de rechte tellingen dan voor de samenhangen tussen opleiding en arbeidsmarktuitkomsten en deze samenhangen niet anders worden door het al dan niet gebruiken van wegingen.

We zullen in de eerste plaats nagaan of de mensen die afzien van activiteit op de arbeidsmarkt een selectieve groep is. In de tweede plaats kijken we dan in hoeverre de kans dat iemand, die wil werken ook werk heeft, dat wil zeggen tot de werkzame beroepsbevolking behoort. In de derde plaats kijken we naar de aard van het beroep dat de werkzame personen hebben. We gebruiken hier drie indicatoren: (1) de aard van het arbeidscontract, (2) de omvang van de werkweek en (3) de hoogte van het beroep.

Voor we de empirische gegevens bespreken, snijden we nog het discussiepunt aan of het nodig is rekening te houden met sociale herkomst in de statistische analyse. Er lijken goede redenen te zijn om dat te doen. We weten immers dat sociale herkomst, gemeten door het ouderlijk opleidings- en beroepsniveau, zowel van invloed is op iemands opleiding als op zijn of haar beroepskansen (Blau \& Duncan, 1967; De Graaf \& Luijkx, 1992). Het geschatte effect van opleiding op beroep wordt kleiner, wanneer er wordt gecontroleerd voor sociale herkomst. Toch is het de vraag of deze statistische controle noodzakelijk is. Het is duidelijk dat de invloed van het opleidingsniveau op de bereikte beroepspositie twee werkzame bestanddelen heeft: kwalificatie en selectie. Kwalificatie staat voor alle kennis en vaardigheden die worden opgedaan in het onderwijs. Selectie verwijst naar alle kenmerken waarop het onderwijs selecteert. Die kenmerken kunnen sociale herkomst zijn, maar ook aangeboren intelligentie, inzet en andere relevante zaken. In ons onderzoek willen we dit onderscheid niet maken we zouden ook niet kunnen, want de gebruikte microdata bevatten geen informatie over sociale herkomst, intelligentie en inzet - en kijken we naar de totale verschillen tussen hoger en lager opgeleiden op de arbeidsmarkt. 
Het opleidingsniveau van individuen stellen we vast aan de hand van de Standaard Onderwijs Indeling (SOI) van het CBS. De volgende vijfdeling wordt daarbij gehanteerd:

1 basisonderwijs (bo);

2 lager secundair onderwijs (vmbo);

3 hoger secundair onderwijs (mbo/havo/vwo);

4 hoger beroepsonderwijs (hbo);

5 wetenschappelijk onderwijs (wo).

De arbeidsmarktpositie van individuen bepalen we aan de hand van een reeks van indicatoren. In de eerste plaats stellen we vast of iemand al dan niet tot de beroepsbevolking hoort. Dit komt erop neer dat we kijken of mensen betaald werk hebben (of zoeken), waarbij mensen die niet zoeken naar betaald werk niet tot de beroepsbevolking horen. In de tweede plaats richten we ons op het hebben van werk tegenover werkloosheid. In de derde plaats kijken we naar de aard van het werk. We stellen vast of iemand een vaste aanstelling heeft dan wel in tijdelijke dienst is of als zelfstandige werkzaam is. In de vierde plaats onderzoeken we de omvang van de werkweek. Degenen, die maximaal 34 uur per week werk hebben, beschouwen we als deeltijd werkenden. Individuen die meer dan 34 uur werken, zijn voltijds werkzaam. In de vijfde plaats wordt de hoogte van het beroep bestudeerd. Dit doen we op twee manieren. We bepalen allereerst het beroepsniveau volgens de Standaard Beroepen Classificatie (SBC) van het CBS. Hierin wordt een vijfdeling gebruikt voor het beroepsniveau:

1 elementaire beroepen;

2 lagere beroepen;

3 middelbare beroepen;

4 hogere beroepen;

5 wetenschappelijke beroepen.

Het is duidelijk dat de twee indelingen sterk op elkaar lijken. De empirische correlatie tussen opleidings- en beroepsniveau is tamelijk hoog, maar lang niet perfect $(\mathrm{r}=0,7)$. Een vergelijking tussen het opleidings- en beroepsniveau van werkenden stelt ons in staat ontwikkelingen in over- en onderscholing vast te stellen. Wanneer het opleidingsniveau hoger is dan het beroepsniveau spreken we van overscholing. Als het beroepsniveau hoger is, dan is men onderschoold. Daarnaast bepalen we de hoogte van het beroep aan de hand van de sociaaleconomische status ervan. Hiervoor 
gebruiken we de internationaal veel gebruikte International Socio-Economic Index (ISEI) (Ganzeboom, De Graaf \& Treiman, 1992; Ganzeboom \& Treiman, 1996). Dit is een schaal die loopt van 16 voor beroepen met de laagste status tot 90 voor beroepen met de hoogste status.

De meeste cijfers presenteren we voor verschillende jaren (1993-2011) dan wel opeenvolgende geboortecohorten (1929-39, 1940-49, 1950-59, 196069, 1970-79, 1980-86) en veelal voor mannen en vrouwen apart. Bij de multivariate analyse van beroepsstatus houden we eveneens rekening met leeftijdsverschillen. Meer in het algemeen geldt dat we een leeftijdsselectie toepassen van 25-64 jarigen. Jongere respondenten analyseren we niet, omdat zij vaak nog op school zitten en de relatie tussen opleidingsniveau en arbeidsmarkuitkomsten voor mensen jonger dan 25 vertekend zou zijn.

\section{Resultaten}

Tabel 1 laat aan de hand van een vergelijking van geboortecohorten zien dat het opleidingsniveau van de Nederlandse bevolking sterk is gestegen in de loop van de tijd. Het percentage personen zonder startkwalificatie (bo of vmbo) is gedaald van 54 procent voor het geboortecohort 1929-1939 naar 19 procent voor het cohort 1980-1986. Het percentage mensen met hoger onderwijs (hbo of wo) is daarentegen sterk gestegen: van 15 naar 37 procent. Voor vrouwen is deze ontwikkeling sterker geweest dan voor mannen: vrouwen waren vroeger lager opgeleid dan mannen; tegenwoordig is het precies andersom. Vrouwen hebben nu een voorsprong in het onderwijs. Voor het jongste cohort geldt bijvoorbeeld dat 41 procent van de vrouwen een opleiding in het hoger onderwijs heeft behaald tegenover 33 procent van de mannen.

Deze voorsprong in het onderwijs van de jongste generatie van vrouwen vertaalt zich op de lange termijn mogelijk door op de arbeidsmarkt. Vooralsnog is dit echter niet het geval. Uit tabel 2 komt naar voren dat de arbeidsmarktpositie van vrouwen beduidend achterblijft bij die van mannen. In de eerste plaats is de arbeidsmarktparticipatie van mannen flink hoger: 83 procent van de mannen tegenover 66 procent van de vrouwen neemt deel aan het arbeidsproces. Dit geldt voor alle opleidingsniveaus, maar de sekseverschillen zijn verreweg het grootst bij de lagere niveaus. Zowel vraag- als aanbodfactoren spelen hierbij een rol. Over het algemeen geldt dat hoger opgeleiden veel vaker deelnemen aan het arbeidsproces dan lager opgeleiden. In 2011 was ongeveer de helft van degenen met alleen basisonderwijs actief op de arbeidsmarkt, terwijl dit aandeel onder acade- 
Tabel 1 Opleidingsniveau naar geboortecohort en geslacht (\%)

\begin{tabular}{|c|c|c|c|c|c|c|}
\hline & \multicolumn{6}{|c|}{ Geboortecohort } \\
\hline & 1929-39 & $1940-49$ & $1950-59$ & $1960-69$ & $1970-79$ & $1980-86$ \\
\hline \multicolumn{7}{|l|}{ Allen } \\
\hline bo & 24,8 & 15,6 & 10,9 & 7,1 & 5,5 & 4,3 \\
\hline vmbo & 28,9 & 28,5 & 23,3 & 20,8 & 16,7 & 14,6 \\
\hline mbo/havo/vwo & 31,2 & 34,5 & 39,3 & 45,6 & 46,0 & 44,6 \\
\hline hbo & 11,4 & 14,8 & 18,0 & 17,4 & 20,7 & 25,2 \\
\hline wo & 3,7 & 6,7 & 8,5 & 8,9 & 11,1 & 11,3 \\
\hline \multicolumn{7}{|l|}{ Mannen } \\
\hline bo & 19,7 & 13,3 & 9,4 & 7,0 & 5,6 & 4,5 \\
\hline vmbo & 21,7 & 20,8 & 19,7 & 20,6 & 17,8 & 16,8 \\
\hline mbo/havo/vwo & 38,5 & 38,9 & 40,5 & 44,1 & 45,6 & 46,2 \\
\hline hbo & 14,1 & 17,1 & 19,0 & 17,7 & 19,7 & 22,4 \\
\hline wo & 6,0 & 9,9 & 11,4 & 10,7 & 11,3 & 10,2 \\
\hline \multicolumn{7}{|l|}{ Vrouwen } \\
\hline bo & 29,9 & 17,8 & 12,5 & 7,2 & 5,3 & 4,0 \\
\hline vmbo & 35,9 & 36,2 & 26,9 & 21,1 & 15,7 & 12,5 \\
\hline mbo/havo/vwo & 24,0 & 30,1 & 38,0 & 47,1 & 46,3 & 43,0 \\
\hline hbo & 8,7 & 12,5 & 16,9 & 17,2 & 21,7 & 28,2 \\
\hline wo & 1,5 & 3,4 & 5,6 & 7,3 & 11,0 & 12,3 \\
\hline
\end{tabular}

BRON: EBB 1993-2011, leeftijd 25-64, $\mathrm{N}=615.905$ mannen en $\mathrm{N}=630.624$ vrouwen

misch opgeleiden bijna 90 procent bedroeg. In de tweede plaats werken vrouwen veel frequenter in deeltijd dan mannen. Bijna drie kwart van de vrouwen werkt minder dan 34 uur per week, terwijl dit percentage bij mannen 12 procent bedraagt. Bij mannen met een diploma in het hoger onderwijs is dit percentage iets hoger dan bij lager opgeleide mannen. Voor vrouwen geldt juist het omgekeerde: hoger opgeleide vrouwen werken meer uren dan lager opgeleide vrouwen. In de derde plaats hebben vrouwen iets vaker een tijdelijke baan dan mannen. Ze zijn eveneens iets meer in vaste dienst werkzaam, maar dit komt vooral omdat mannen vaker als zelfstandige werken. Tijdelijk werk manifesteert zich met name onder lager opgeleiden. Zelfstandigen zijn daarentegen het sterkst vertegenwoordigd in de categorie van academisch opgeleiden. In de vierde plaats zijn vrouwen iets vaker in lagere beroepen werkzaam dan mannen. Dit komt vooral tot uitdrukking als we kijken naar degenen zonder startkwalificatie. Bij vrouwen met een vmbo-opleiding is 20 procent in een elementair beroep werkzaam; bij mannen met hetzelfde opleidingsniveau is dit 11 procent. Bij individuen zonder enig diploma is dit verschil nog groter: 34 procent van de vrouwen met alleen basisonderwijs heeft een elementair 
beroep tegenover 20 procent van de mannen. Voor een deel kunnen deze verschillen te maken hebben met een uiteenlopend loopbaanperspectief tussen laagopgeleide mannen en vrouwen. De ruimere werkervaring van laagopgeleide mannen maakt dat ze wellicht vaker promotie maken en daardoor in een hoger beroepsniveau terechtkomen tijdens de loopbaan dan laagopgeleide vrouwen.

$\mathrm{Nu}$ we een algemeen beeld hebben geschetst van de huidige arbeidsmarktpositie van de Nederlandse (beroeps)bevolking naar opleiding en geslacht, gaan we vervolgens dieper in op recente ontwikkelingen in de belangrijkste indicatoren van de arbeidsmarktpositie. Deze ontwikkelingen beslaan de periode 1993-2011; het tijdperk waarover we gegevens presenteren in deze bijdrage. In figuur 1 starten we met ontwikkelingen in de arbeidsmarktdeelname. De arbeidsmarktparticipatie is behoorlijk gestegen in de afgelopen twee decennia. Deze bedroeg gemiddeld genomen 65 procent in 1993 en 79 procent in 2011. Met name onder lager opgeleiden is een sterke toename te zien. Dit is vooral een inhaaleffect. Hoewel mannen ook ietwat vaker zijn gaan participeren in de loop van de tijd (een gemiddelde stijging van vier procentpunten over alle opleidingsniveaus heen) is de toename in de arbeidsmarktparticipatie vooral veroorzaakt door vrouwen. In 1993 was minder dan de helft van hen werkzaam, terwijl dit in $20117^{0}$ procent betrof. Vooral onder laagopgeleide vrouwen is de arbeidsmarktdeelname flink toegenomen, waardoor voor vrouwen de negatieve samenhang tussen arbeidsmarktparticipatie en opleidingsniveau is afgenomen in de loop van de tijd. Tot slot is de toename in de arbeidsmarktparticipatie het gevolg van de stijging van het opleidingsniveau van de bevolking. Omdat er in de loop van de tijd (relatief gezien) steeds meer hoger opgeleiden bij zijn gekomen en zij een grotere arbeidsmarktdeelname kennen dan lager opgeleiden, is de arbeidsmarktparticipatie in de voorbij twintig jaar gestegen.

De kans op werk is sterk conjunctureel bepaald: tijdens laagconjunctuur (in het begin van de jaren negentig en de jaren 2000) is deze kans geringer dan ten tijde van hoogconjunctuur (zie figuur 2). Dit geldt zowel voor de onderscheiden opleidingsniveaus als voor mannen en vrouwen. Verder valt uit deze figuur op te maken dat er een positief verband is tussen het opleidingsniveau van individuen en hun kans op werk. Mannen zonder enig diploma hebben een relatief grote kans op werkloosheid, terwijl dat ook geldt voor vrouwen met alleen een vmbo-opleiding. Er zijn geen trends in de samenhang tussen opleidingsniveau en kans op werk geconstateerd. De associatie (uitgedrukt in termen van odds ratio's waarbij wo en basisonderwijs met elkaar worden vergeleken) is vrij constant: ongeveer 2,7. Dit is 
Tabel 2 Arbeidsmarktpositie naar opleidingsniveau en geslacht in 2011 (\%)

\begin{tabular}{|c|c|c|c|c|c|c|}
\hline & \multicolumn{6}{|c|}{ Opleidingsniveau } \\
\hline & wo & hbo & $\begin{array}{r}\text { mbo/havo/ } \\
\text { vwo }\end{array}$ & vmbo & bo & allen \\
\hline Mannen & $(12,1)$ & $(21,7)$ & $(40,6)$ & $(19,1)$ & $(6,5)$ & $(100)$ \\
\hline niet op zoek naar werk & 7,1 & 8,3 & 11,6 & 16,1 & 30,7 & 12,4 \\
\hline werkloos & 3,6 & 3,9 & 4,3 & 4,9 & 5,7 & 4,3 \\
\hline werkend & 89,3 & 87,7 & 84,1 & 79,0 & 63,6 & 83,2 \\
\hline wetenschappelijke beroepen & 60,1 & 10,4 & 2,8 & 0,9 & 1,1 & 11,5 \\
\hline hogere beroepen & 26,9 & 64,4 & 13,5 & 5,9 & 2,9 & 24,9 \\
\hline middelbare beroepen & 9,9 & 20,0 & 59,8 & 33,4 & 22,2 & 37,6 \\
\hline lagere beroepen & 2,4 & 4,0 & 19,2 & 49,1 & 54,2 & 20,7 \\
\hline elementaire beroepen & 0,7 & 1,2 & 4,8 & 10,8 & 19,6 & 5,3 \\
\hline voltijd (meer dan 34 uur per week) & 82,4 & 85,0 & 87,9 & 88,9 & 86,1 & 87,9 \\
\hline deeltijd & 17,6 & 15,0 & 12,1 & 11,1 & 13,9 & 12,1 \\
\hline vaste baan & 70,3 & 77,1 & 72,9 & 72,9 & 69,5 & 73,4 \\
\hline tijdelijke baan & 7,4 & 7,6 & 9,8 & 10,6 & 13,6 & 9,3 \\
\hline \multirow[t]{2}{*}{ zelfstandige } & 22,3 & 15,4 & 17,2 & 16,5 & 16,9 & 17,3 \\
\hline & 100,0 & 100,0 & 100,0 & 100,0 & 100,0 & 100,0 \\
\hline Vrouwen & $(9,5)$ & $(21,0)$ & $(41,6)$ & $(20,6)$ & $(7,3)$ & (100) \\
\hline niet op zoek naar werk & 13,3 & 16,3 & 25,1 & 47,4 & 64,1 & 29,6 \\
\hline werkloos & 4,5 & 3,4 & 4,9 & 5,2 & 4,4 & 4,6 \\
\hline werkend & 82,1 & 80,3 & 69,9 & 47,4 & 31,5 & 65,8 \\
\hline wetenschappelijke beroepen & 61,3 & 5,3 & 2,4 & 0,7 & 0,4 & 9,8 \\
\hline hogere beroepen & 24,9 & 68,1 & 8,2 & 4,2 & 2,3 & 24,7 \\
\hline middelbare beroepen & 11,2 & 21,3 & 68,0 & 17,2 & 13,0 & 39,9 \\
\hline lagere beroepen & 1,9 & 4,4 & 17,4 & 58,4 & 50,1 & 19,4 \\
\hline elementaire beroepen & 0,7 & 0,9 & 4,1 & 19,5 & 34,2 & 6,2 \\
\hline voltijd (meer dan 34 uur per week) & 43,4 & 31,5 & 21,8 & 21,1 & 22,1 & 26,7 \\
\hline deeltijd & 56,6 & 68,5 & 78,2 & 78,9 & 77,9 & 73,3 \\
\hline vaste baan & 71,1 & 80,3 & 78,3 & 76,5 & 73,0 & 77,5 \\
\hline tijdelijke baan & 10,3 & 10,3 & 12,0 & 14,1 & 16,4 & 12,2 \\
\hline \multirow[t]{2}{*}{ zelfstandige } & 15,3 & 9,4 & 9,7 & 9,4 & 10,6 & 10,3 \\
\hline & 100,0 & 100,0 & 100,0 & 100,0 & 100,0 & 100,0 \\
\hline
\end{tabular}

BRON: EBB-2011, leeftijd 25-64, $\mathrm{N}=29.316$ mannen en $\mathrm{N}=30.769$ vrouwen 
in tegenspraak met wat wel wordt gesuggereerd (Dekker, 2014) en ook in de eerdere WRR-studie is gevonden (De Graaf, 1996), namelijk dat de relatieve kans op werk voor laagopgeleiden verslechtert in tijden van laagconjunctuur.

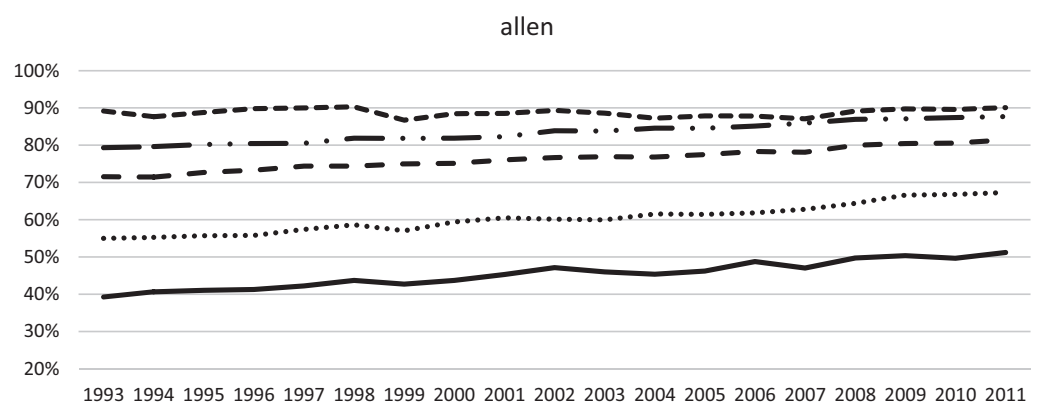

mannen

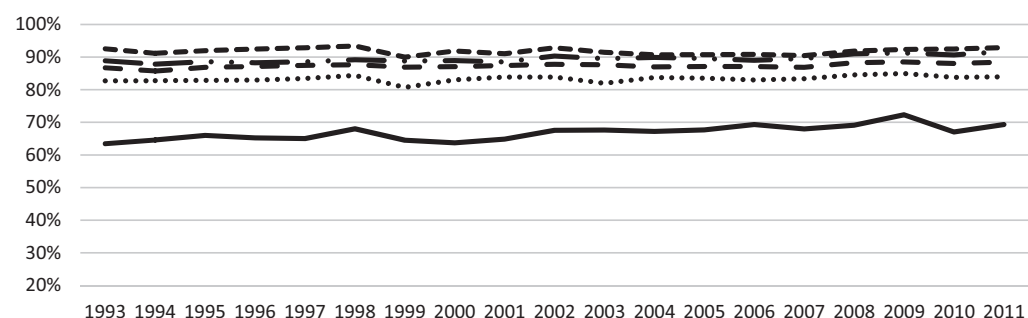

vrouwen

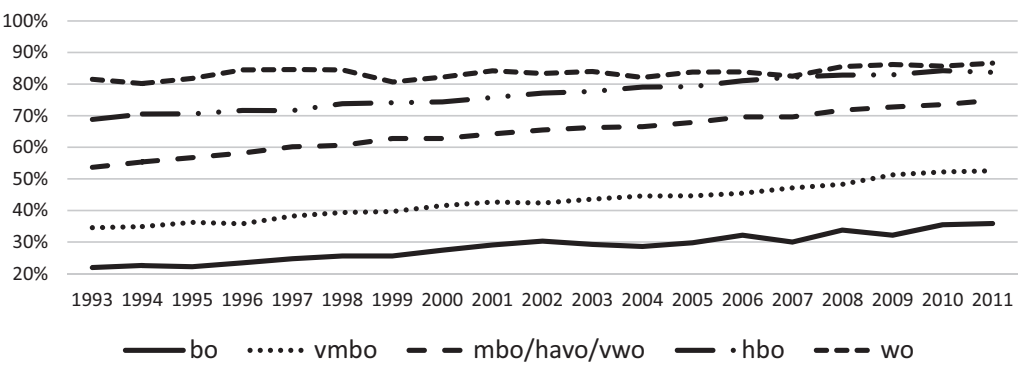

Figuur 1 Behorend tot de actieve beroepsbevolking naar opleidingsniveau, geslacht en jaar Bron: EBB 1993-2011, als percentage van de potentiële beroepsbevolking, leeftijd 25-64, N =608.334 mannen en $\mathrm{N}=626.161$ vrouwen 
allen

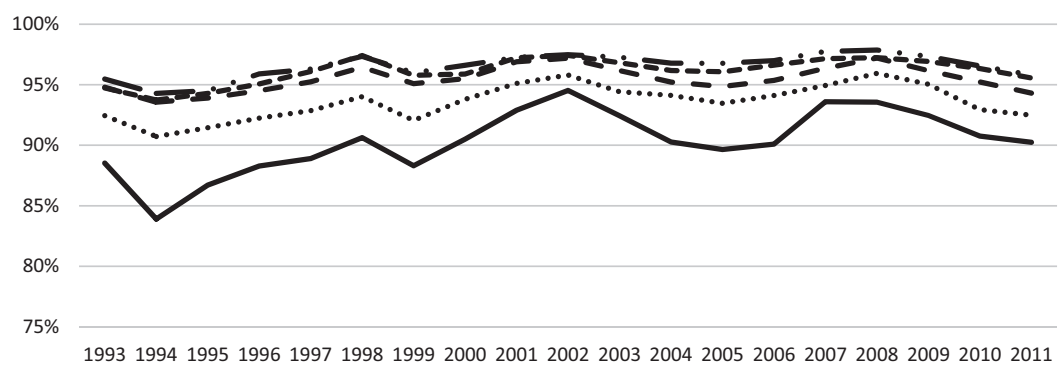

mannen

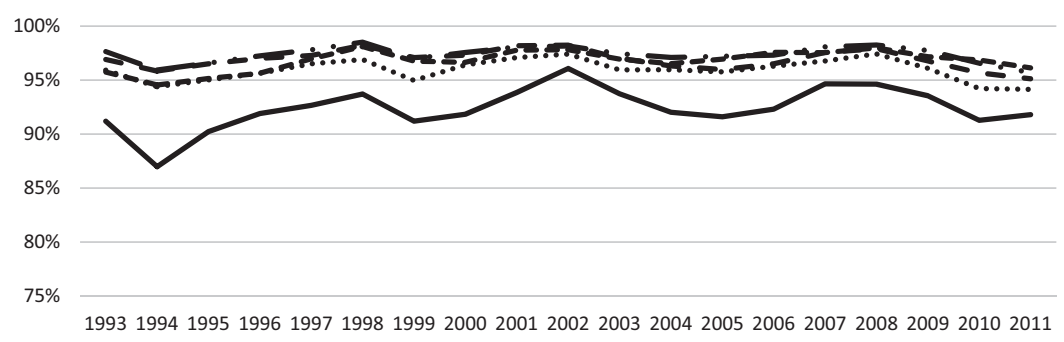

vrouwen

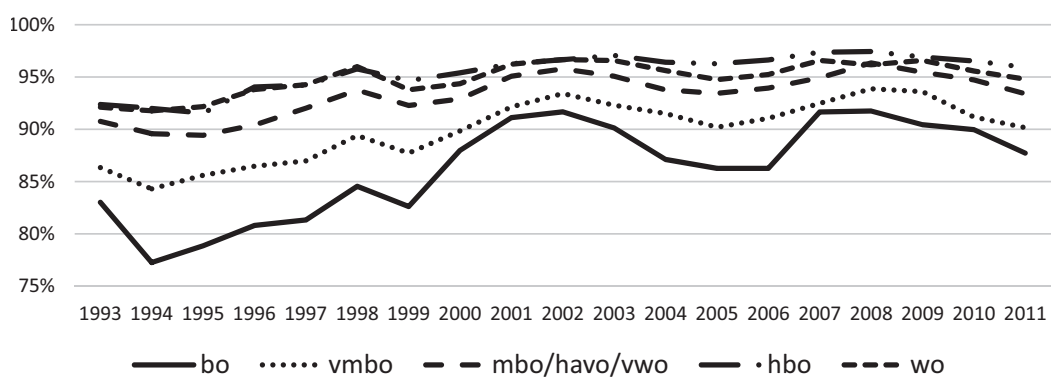

Figuur 2 De kans op werk naar opleidingsniveau, geslacht en jaar

Bron: EBB 1993-2011, als percentage van de actieve beroepsbevolking, leeftijd 25-64, N = 519.565 mannen en $\mathrm{N}=363.632$ vrouwen

Het percentage mannen en vrouwen dat in voltijd werkt, is behoorlijk afgenomen in de periode 1993-2011: van 75 naar 59 procent (zie figuur 3). Deze afname heeft er onder meer mee te maken dat nogal wat jonge vaders en de meeste moeders kiezen voor een deeltijdbaan in plaats van een voltijdbaan. Voor mannen is er nauwelijks een samenhang tussen het opleidingsniveau van individuen en de omvang van hun werkweek. Bij vrouwen is er wel een duidelijk verband te zien: hoger opgeleide vrouwen werken vaker in voltijd 
dan lager opgeleide vrouwen. In 2011 bedroeg het verschil tussen vrouwen met een universitaire graad en vrouwen zonder enig diploma 21 procentpunten. Deze samenhang is niet veranderd in de loop van de tijd.

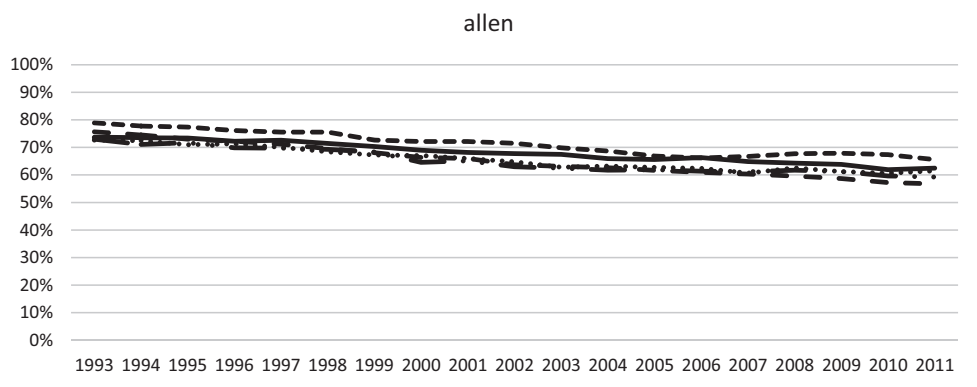

mannen

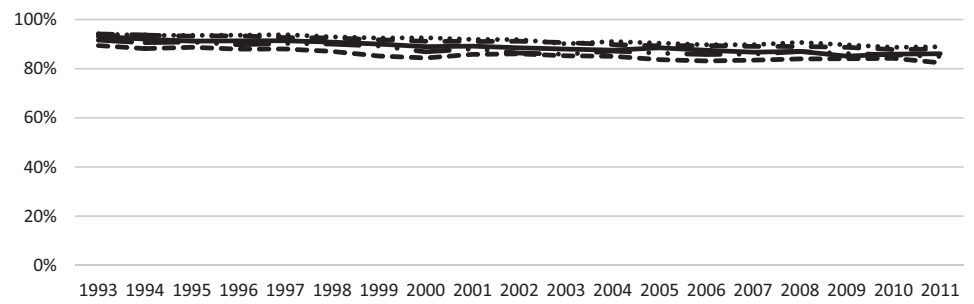

vrouwen

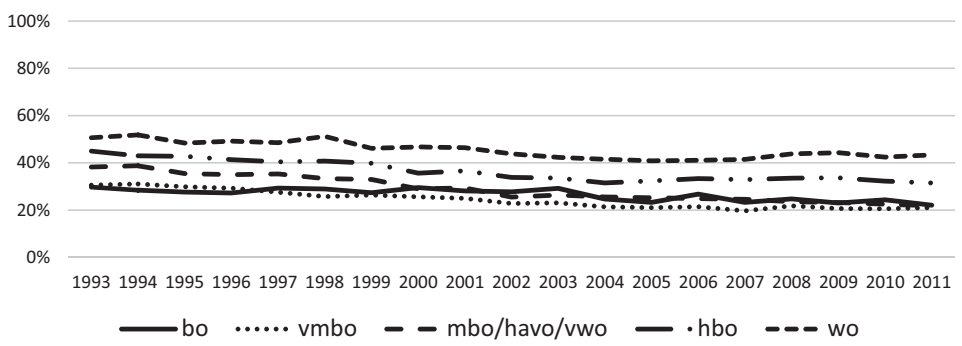

Figuur 3 Voltijds baan (34 uur per week of meer) naar opleidingsniveau, geslacht en jaar Bron: EBB 1993-2011, als percentage van de werkzame beroepsbevolking, leeftijd 25-64, N = 501.131 mannen en $N=338.397$ vrouwen

Figuur 4 toont dat de vaste baan op zijn retour is, voor iedereen. Over de gehele periode betreft de afname acht procentpunten (van 83 procent met een vaste baan in 1993 naar 75 procent in 2011). Steeds meer mensen bevinden zich in een tijdelijk dienstverband of zijn werkzaam als zelfstandige (zonder personeel). Hoger opgeleiden hebben een grotere kans op vast werk dan lager opgeleiden. Een uitzondering geldt voor academisch opgeleiden. 
Zij hebben minder vaak een vaste aanstelling dan bijvoorbeeld personen met een hbo-opleiding (en even vaak als individuen zonder enig diploma). Dit betekent echter niet dat academici vaker in een tijdelijke baan werkzaam zijn dan hbo'ers. Eerstgenoemden werken vaker als zelfstandige (zie tabel 2).

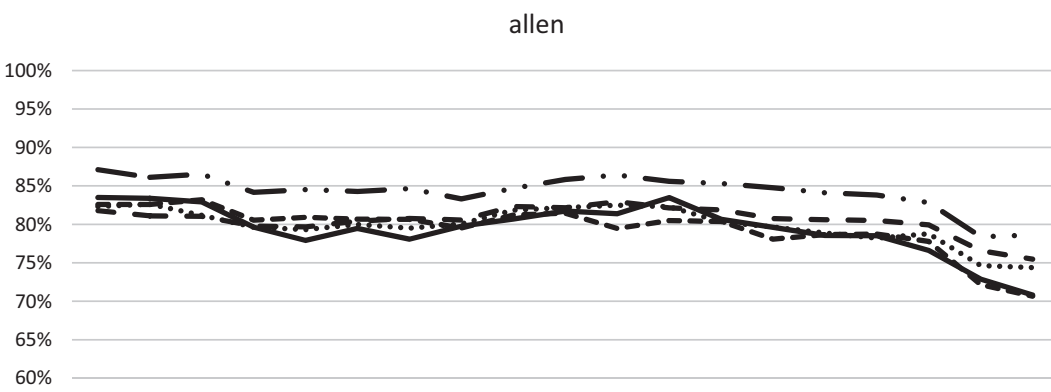

1993199419951996199719981999200020012002200320042005200620072008200920102011 mannen
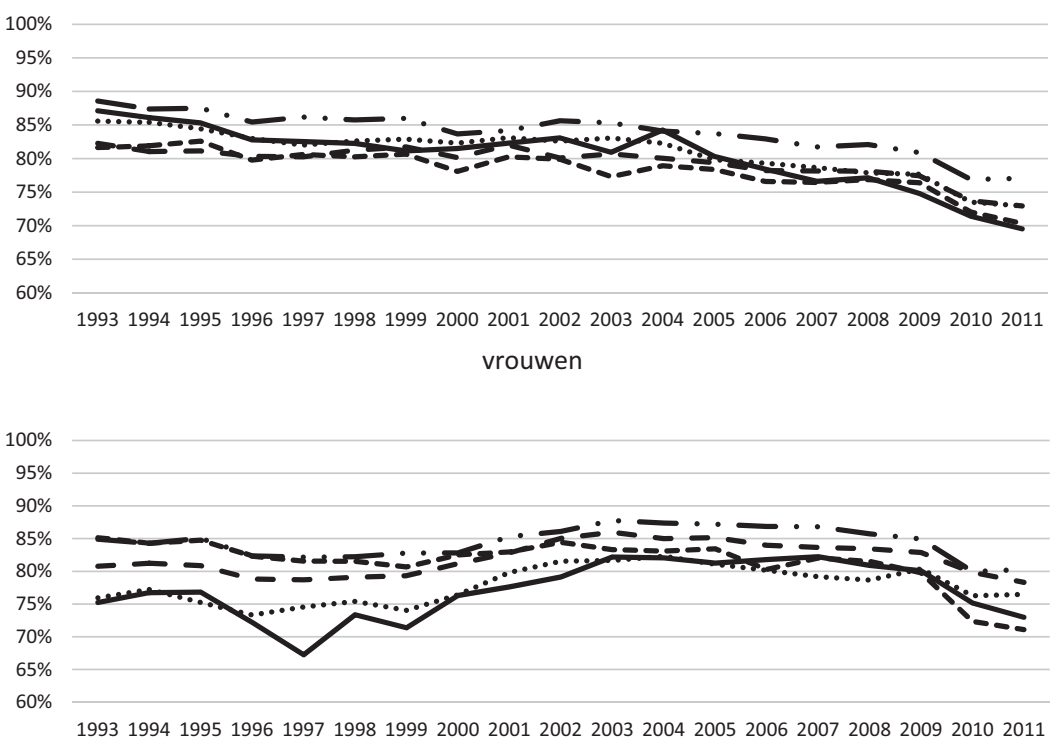

Figuur 4 Vast arbeidscontract naar opleidingsniveau, geslacht en jaar

Bron: EBB 1993-2011, als percentage van de werkzame beroepsbevolking, leeftijd 25-64, $\mathrm{N}=501.131$ mannen en $\mathrm{N}=338.397$ vrouwen

Tabellen $3^{\mathrm{a}}$ en $3 \mathrm{~b}$ richten zich op het verband tussen opleidings- en beroepsniveau, apart voor 1993 en 2011. In beide jaren geldt dat mensen met een bepaald opleidingsniveau over het algemeen in een beroep van hetzelfde niveau terechtkomen (zie het bovenste gedeelte van de tabel), en 
andersom, dat mensen met een bepaald beroepsniveau vooral worden geworven uit de groep met het overeenkomstige opleidingsniveau (zie het onderste gedeelte van de tabel). Dit is te zien in de vetgedrukte diagonaalcellen van de subtabellen. Zowel in 1993 als in 2011 geldt dat de aansluiting tussen opleiding en beroep het zwakst is voor mensen zonder enige startkwalificatie. De percentages in de diagonaalcellen zijn het laagst voor personen die geen diploma hebben of niet meer dan een diploma in het vmbo. De buitendiagonaalcellen geven zicht op de 'mismatches' tussen opleiding en beroep. In het bovenste gedeelte van de tabellen hebben deze discrepanties tussen opleiding en beroep betrekking op over- en onderscholing. We constateren bijvoorbeeld dat in 2011 van alle academisch opgeleiden 61 procent in wetenschappelijke beroepen werkzaam was, terwijl dat in 1993 nog 74 procent was. De overigen zijn werkzaam in een beroep waarvoor een lager opleidingsniveau is vereist. Deze personen kunnen als overschoold worden bestempeld. Voor hbo'ers kunnen we soortgelijke uitspraken doen. In 2011 is 66 procent werkzaam op het eigen niveau, 26 procent is overschoold en acht procent is onderschoold (dat wil zeggen, werkzaam in een hoger beroep). Onderscholing komt het meest voor bij de laagst opgeleiden. We zien dat in 2011 slechts 25 procent van degenen zonder diploma in elementaire beroepen werkzaam zijn; ruim de helft heeft een hoger beroep. Dit resultaat verwijst overigens waarschijnlijk niet alleen op onderscholing; een gedeelte van deze personen heeft via opwaartse carrièremobiliteit een hoger beroep bereikt dan oorspronkelijk voor hen was 'weggelegd'.

De verschillen tussen 1993 en 2011 zijn vooral in de hoogste categorieën te vinden. Bovenaan is het duidelijk dat diploma's wat minder waard zijn geworden. Minder wo-ers en hbo-ers komen op hun eigen niveau terecht. Onderaan geldt dat er minder veranderingen zijn, maar het is wel opvallend dat in 2011 nog maar 19 procent van de mensen die in elementaire beroepen geen diploma hebben. De grote meerderheid is overschoold. Ook in de lagere beroepen is bijna de helft overschoold: terwijl het betreffende percentage in 1993 nog 36 procent was, bedroeg het in 2011 al 45 procent. 
Tabel 3a Opleidings- en beroepsniveau in 1993 (\%)

\begin{tabular}{|c|c|c|c|c|c|c|}
\hline \multicolumn{7}{|l|}{ Beroep naar opleiding } \\
\hline & \multicolumn{6}{|c|}{ Opleidingsniveau } \\
\hline & wo & hbo & $\begin{array}{r}\text { mbo/ } \\
\text { havo/vwo }\end{array}$ & vmbo & bo & allen \\
\hline wetenschappelijke beroepen & 74 & 8 & 2 & 1 & 0 & 8 \\
\hline hogere beroepen & 18 & 70 & 13 & 4 & 3 & 21 \\
\hline middelbare beroepen & 5 & 19 & 65 & 33 & 22 & 41 \\
\hline lagere beroepen & 2 & 4 & 18 & 51 & 51 & 24 \\
\hline \multirow[t]{2}{*}{ elementaire beroepen } & 0 & 0 & 3 & 11 & 23 & 6 \\
\hline & 100 & 100 & 100 & 100 & 100 & 100 \\
\hline \multicolumn{7}{|l|}{ Opleiding naar beroep } \\
\hline wetenschappelijke beroepen & 71 & 18 & 10 & 1 & 0 & 100 \\
\hline hogere beroepen & 7 & 62 & 26 & 4 & 1 & 100 \\
\hline middelbare beroepen & 1 & 8 & 69 & 17 & 5 & 100 \\
\hline lagere beroepen & 1 & 3 & 32 & 46 & 19 & 100 \\
\hline elementaire beroepen & 0 & 1 & 22 & 41 & 35 & 100 \\
\hline allen & 8 & 19 & 43 & 22 & 9 & 100 \\
\hline
\end{tabular}

Bron: EBB 1993, leeftijd 25-64, werkzame beroepsbevolking, $N=38.766$ individuen

Tabel 3b Opleidings- en beroepsniveau in 2011 (\%)

\begin{tabular}{|c|c|c|c|c|c|c|}
\hline \multicolumn{7}{|l|}{ Beroep naar opleiding } \\
\hline & \multicolumn{6}{|c|}{ Opleidingsniveau } \\
\hline & wo & hbo & $\begin{array}{r}\text { mbo/ } \\
\text { havo/vwo }\end{array}$ & vmbo & bo & allen \\
\hline wetenschappelijke beroepen & 61 & 8 & 3 & 1 & 1 & 11 \\
\hline hogere beroepen & 26 & 66 & 11 & 5 & 3 & 25 \\
\hline middelbare beroepen & 10 & 21 & 64 & 27 & 19 & 39 \\
\hline lagere beroepen & 2 & 4 & 18 & 53 & 53 & 20 \\
\hline \multirow[t]{2}{*}{ elementaire beroepen } & 1 & 1 & 5 & 14 & 25 & 6 \\
\hline & 100 & 100 & 100 & 100 & 100 & 100 \\
\hline \multicolumn{7}{|l|}{ Opleiding naar beroep } \\
\hline wetenschappelijke beroepen & 70 & 18 & 10 & 1 & 0 & 100 \\
\hline hogere beroepen & 13 & 64 & 19 & 3 & 1 & 100 \\
\hline middelbare beroepen & 3 & 13 & 70 & 12 & 2 & 100 \\
\hline lagere beroepen & 1 & 5 & 39 & 44 & 11 & 100 \\
\hline elementaire beroepen & 2 & 4 & 33 & 42 & 19 & 100 \\
\hline allen & 13 & 24 & 43 & 17 & 4 & 100 \\
\hline
\end{tabular}

BRON: EBB 2011, leeftijd 25-64, werkzame beroepsbevolking, $\mathrm{N}=44.650$ individuen 
Figuur 5 toont vervolgens de algemene ontwikkelingen in over- en onderscholing tussen 1993 en 2011. We concluderen dat er in het bestudeerde tijdvak wat meer overscholing en wat minder onderscholing is gekomen, maar dramatische ontwikkelingen zijn hier niet te zien. De ontwikkelingen zijn eraan toe te schrijven dat de technologische opwaardering van de beroepsarbeid minder snel is gegaan dan de groei in het onderwijsniveau van de (beroeps)bevolking. Figuur 5 laat niet zien dat de verschillen tussen mannen en vrouwen gering zijn.

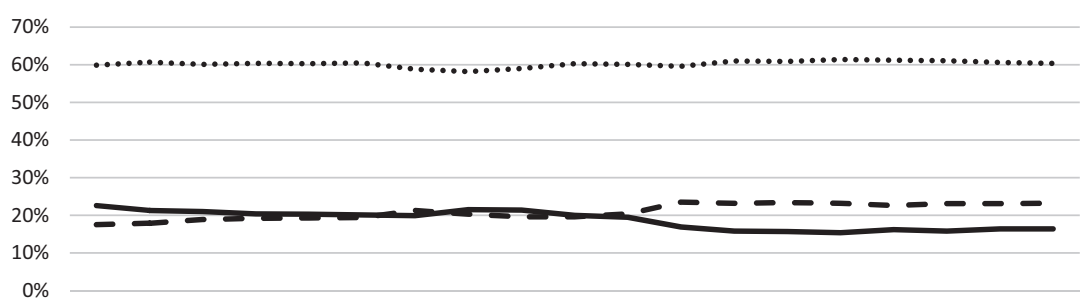

1993199419951996199719981999200020012002200320042005200620072008200920102011

—onderschoold ...... juist geschoold _ - overschoold

Figuur 5 Over- en onderscholing tussen 1993 en 2011

Bron: EBB 1993-2011, als percentage van de werkzame beroepsbevolking, leeftijd 25-64, N = 839.528 individuen

Ten slotte presenteren we ontwikkelingen in de waarde van diploma's op de arbeidsmarkt ook nog eens vanuit een cohortperspectief, wat een scherper beeld oplevert dan het periode-perspectief in de vorige analyses. Voor elk opleidingsniveau apart kijken we naar de ontwikkelingen van het beroepsniveau (in termen van beroepsstatus) tussen geboortecohorten, waarbij we met behulp van lineaire regressie-analyse constant houden voor de leeftijd van de respondenten (en geslacht in het model voor mannen en vrouwen gezamenlijk). Statistische controle voor leeftijd is belangrijk, omdat de eerder geboren cohorten op het moment van observatie ouder zijn, en daarmee verder in hun beroepsloopbaan gevorderd zijn, dan de later geboren cohorten. Het cohorteffect wordt op deze manier gecorrigeerd voor het loopbaaneffect, dat wordt geschat door een lineaire en kwadratische term zodat we de afvlakkende curve van status over de levensloop goed modelleren. In figuur 6 worden de uitkomsten van de modellen geprojecteerd (en in tabellen A.1 en A.2 van de Appendix zijn de geschatte regressiecoëfficiënten weergegeven). We laten opleidingsverschillen op 25-jarige leeftijd zien. Als we naar het totaalbeeld kijken, dan zien we dat het gemiddelde beroepsniveau is toegenomen in de loop van de tijd. Voor het oudste geboortecohort bedroeg de gemiddelde beroeps- 
status 44 punten, terwijl dit voor het jongste cohort 48 statuspunten was. Voor ieder opleidingsniveau afzonderlijk treffen we daarentegen een negatief cohorteffect aan. De afname in het gemiddelde beroepsniveau bedraagt zo'n twee statuspunten. Maar onder academici is de afname een stuk sterker. Voor de onderzochte cohorten bedraagt de waardevermindering in totaal zo'n zeven statuspunten. Blijkbaar is met name de academische graad aan devaluatie onderhevig geweest en vindt overscholing met name onder afgestudeerden van universiteiten plaats. Er zijn wat dit betreft nauwelijks verschillen tussen mannen en vrouwen. We concluderen dat deze bevindingen de baancompetitietheorie ondersteunen. Het beroepsniveau hangt sterk af van de positie die individuen innemen in de denkbeeldige wachtrij naar opleidingsniveau. Daarbij moeten we wel bedenken dat het aantal posities aan de onderkant van de arbeidsmarkt beperkt is en als gevolg daarvan vallen laagopgeleiden buiten de boot. Laagopgeleiden boeten niet zozeer in aan beroepsniveau, maar zij hebben wel een grotere kans op werkloosheid. Toch is het niet zo dat zij relatief vaker zonder werk zijn komen te zitten gedurende de afgelopen twintig jaar, zoals figuur 2 al liet zien.

allen
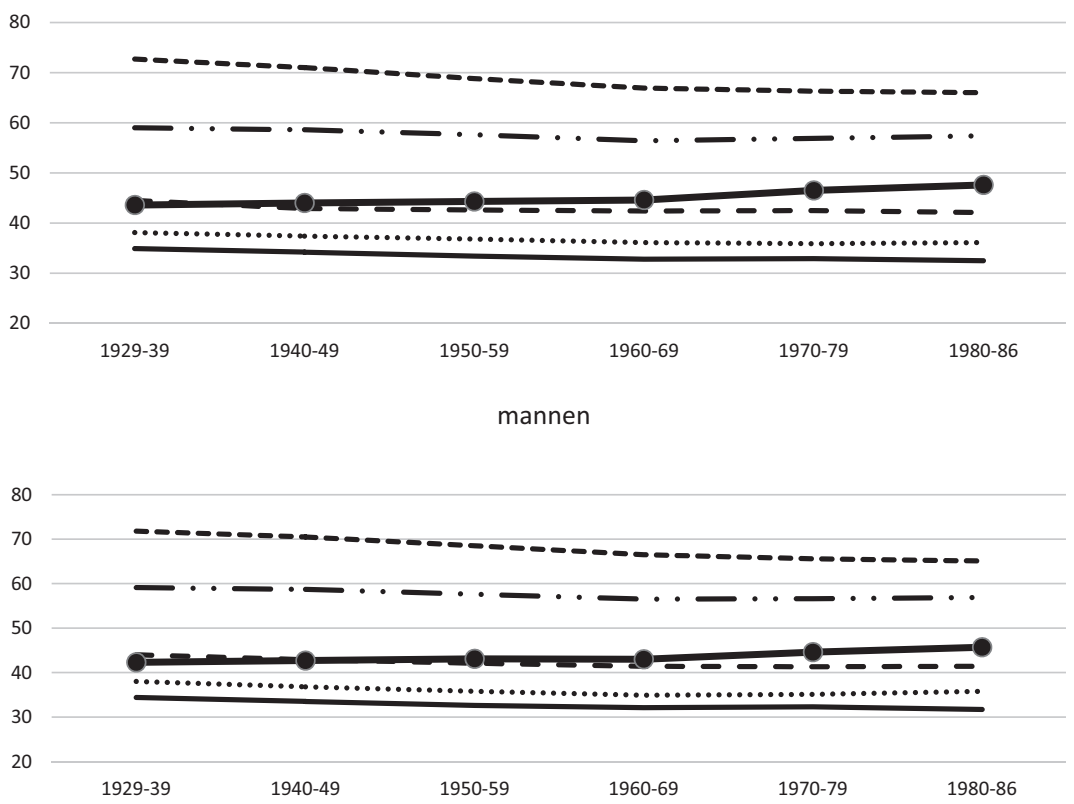


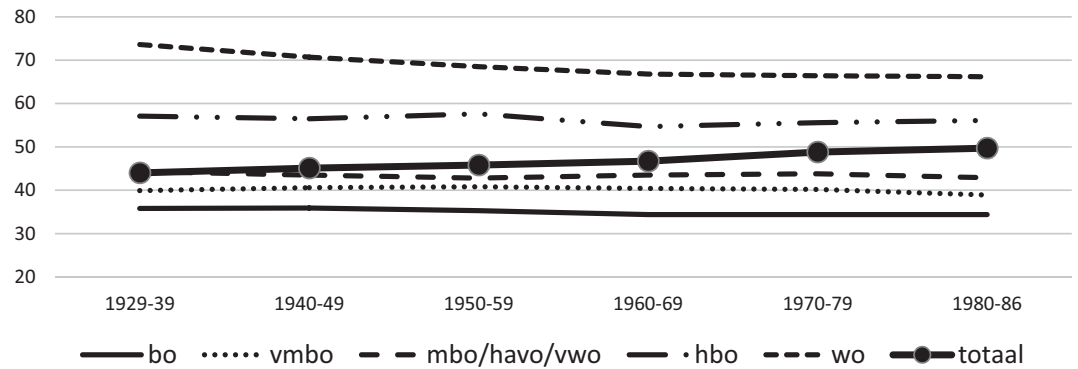

Figuur 6 Beroepsstatus naar opleidingsniveau, geslacht en geboortecohort Bron: EBB 1993-2011, leeftijd 25-64, werkzame beroepsbevolking, $\mathrm{N}=501.131$ mannen en $\mathrm{N}=338.397$ vrouwen

\section{Conclusie}

Zoals we in 1996 reeds vermoedden, is de samenhang tussen opleiding en succes op de arbeidsmarkt zeer groot gebleven. Zonder diploma's heeft iemand maar weinig kans om tot de hogere beroepen door te dringen en andersom, een diploma in het hoger onderwijs zorgt bijna altijd voor een gunstig beroep. De vraag of de verschillen tussen hoger en lager opgeleiden in Nederland zodanig groot zijn dat van een sociale scheidslijn in de samenleving kan worden gesproken, is echter niet met ja of nee te beantwoorden. Inderdaad, voor een gunstige beroepsloopbaan moet men naar school, en zonder diploma's bereik je niet veel, maar dit wordt over het algemeen gezien als een terechte, ja zelfs als de beste manier waarop beschikbare posities op de arbeidsmarkt moeten worden verdeeld. Niet iemands sociale herkomst of andere ascriptieve kenmerken dienen doorslaggevend te zijn, maar de kennis en vaardigheden juist wel. Uiteraard hangt deze laatste redenering af van de meritocratie in het onderwijs: zijn het de getalenteerden die het verst komen of juist degenen met het meeste economische, culturele of sociale kapitaal?

In de periode 1993-2011 heeft de opwaardering van de beroepsarbeid geen gelijke tred gehouden met de opwaardering van het opleidingsniveau van de Nederlandse beroepsbevolking. In vergelijking met mensen met hetzelfde opleiding in 1993, bereiken mensen in 2011 een wat lager beroepsniveau. Vooral mensen met een opleiding in het hbo of het wo zijn erop achteruit gegaan. Ernstiger dan de verschillen in beroepspositie zijn misschien de kansen op betaald werk. Deze kansen verschillen sterk tussen 
hoger en lager opgeleiden. Voor nogal wat lager opgeleiden zijn er geen banen beschikbaar en hoewel we (nog) geen duidelijke trend zien, lijken de vooruitzichten toch niet rooskleurig voor mannen en vrouwen zonder op zijn minst een mbo-diploma. Processen als globalisering (outsourcing van eenvoudig werk naar andere landen) en arbeidsmigratie (van Centraalen Oost-Europeanen naar Nederland) zijn hier niet vreemd aan. Laagopgeleiden worden van de arbeidsmarkt verdrongen. Het is de vraag tot wat voor sociale gevolgen deze ontwikkelingen zullen leiden. Bepaalde sociale en politieke gevolgen zijn wellicht al zichtbaar in de opkomst van bepaalde politieke partijen en andere indicatoren van maatschappelijke onvrede onder de lager opgeleiden. Het zal spannend zijn welke ontwikkeling sneller gaat: de afname van het percentage laagopgeleiden in Nederland of de afname van de werkgelegenheid voor lager opgeleiden. En zal deze spanning zich verplaatsen naar het mbo-niveau waardoor de middenklasse onder druk komt te staan?

Tot besluit willen we graag opmerken dat de meeste veranderingen op de arbeidsmarkt voortkomen uit veranderingen in de marginale verdelingen: de opleidingsverdeling is veranderd en mede daardoor ook het aanbod van arbeid, en ook de vraag naar arbeid is veranderd, maar de relaties tussen onderwijs en arbeid veranderen nauwelijks. De meest opvallende veranderingen die er tussen 1993 en 2011 zijn geweest, kunnen we toeschrijven aan veranderingen in de verdelingen. De gedaalde beroepsstatus van mannen en vrouwen met diploma's in het hoger onderwijs komt doordat er minder banen van hoger en wetenschappelijk niveau bij zijn gekomen dan mensen met zo'n diploma, niet omdat werkgevers in toenemende mate een voorkeur voor werknemers met een middelbaar diploma zouden hebben voor die hogere banen. We verwachten dat ook in de komende jaren de waarde van diploma's vooral wordt bepaald door ontwikkelingen in de vraag en aanbod naar arbeid.

\section{Referenties}

Becker, G.S. (1964). Human capital: A theoretical and empirical analysis with special reference to education. New York: National Bureau of Economic Research.

Blau, P. \& Duncan, O. (1967). The American occupational structure. New York: Wiley \& Sons.

Burris, V. (2005). Overeducation: Then and now. Work and Occupations, 32, 391-321.

Centraal Planbureau (CPB) (1993). Bevolking, opleiding en participatie tot 2015: Drie scenario's. 's Gravenhage: Centraal Planbureau.

Dekker, F. (2014). Debat over tweedeling moet ook over de arbeidsmarkt gaan. Sociale Vraagstukken, 20 november 2014. 
Dirven, H.-J. \& Janssen, B. (2012). De Nederlandse beroepsbevolking: Twee afbakeningen. In CBS, Sociaaleconomische trends, re kwartaal 2012 (pp. 80-89). Den Haag: Centraal Bureau voor de Statistiek.

Ganzeboom, H.B.G., Graaf, P.M. de \& Treiman, D.J. (1992). A standard international socio-economic index of occupational status. Social Science Research, 21, 1-56.

Ganzeboom, H.B.G. \& Treiman D.J. (1996). Internationally comparable measures of occupational status for the 1998 International Standard Classification of Occupations. Social Science Research, 25, 201-239.

Graaf, P.M. de (1996). Onderwijs en arbeidsmarkt: Ontwikkelingen in de waarde van diploma's. In H.B.G. Ganzeboom \& W.C. Ultee (Red.), De sociale segmentatie van Nederland in 2015 (pp. 95118). Den Haag: Wetenschappelijke Raad voor het Regeringsbeleid.

Graaf, P.M. de \& Luijkx, R. (1992). Van 'ascription' naar 'achievement'? Trends in statusverwerving in Nederland tussen 1930 en 1980. Mens \& Maatschappij, 67, 412-433.

Hartog, J. (200o). Overeducation and earnings: Where are we, where should we go? Economics of Education Review, 19, 131-147.

Lutz, B. \& Sengenberger, W. (1974). Arbeitsmarktstrukturen und öffentliche Arbeitsmarktpolitik. Göttingen: Otto Schwartz \& Co.

Spence, M. (1974). Market signalling: Informational transfer in hiring and related screening processes. Cambridge, MA: Harvard University Press.

Tinbergen, J. (1975). Income distribution: Analysis and policy. Amsterdam/Oxford: North-Holland Publishing.

Thurow, L.C. (1975). Generating inequality. New York: Basic Books.

Wolbers, M.H.J. (2011). Dynamiek in overscholing en verdringing op de arbeidsmarkt. Tijdschrift voor Arbeidsvraagstukken, 27, 398-413.

Wolbers, M.H.J., Graaf, P.M. de \& Ultee, W.C. (2001). Trends in the occupational returns to educational credentials in the Dutch labor market: Changes in structures and in the association? Acta Sociologica, 44, 5-19.

\section{Over de auteurs}

Paul M. de Graaf is hoogleraar sociologie aan de Universiteit van Tilburg. Hij doet onderzoek naar sociale ongelijkheid in het onderwijs en op de arbeidsmarkt, met een nadruk op culturele en demografische aspecten van intergenerationele overdrachten.

Postadres: Departement Sociologie, Tilburg School of Social and Behavioral Sciences, Universiteit van Tilburg, Postbus 90153, 5000 LE Tilburg.

E-mail: pdegraaf@uvt.nl

Maarten H.J. Wolbers is hoofd sector Onderwijs van het ITS en bijzonder hoogleraar Onderzoek van onderwijs, Radboud Universiteit. Hij doet onderzoek naar sociale ongelijkheid in Nederland en andere hedendaagse samenlevingen, met name op het terrein van het onderwijs en de arbeidsmarkt. Postadres: Sectie Sociologie, Faculteit der Sociale Wetenschappen, Radboud Universiteit, Postbus 9104, 6500 HE Nijmegen.

E-mail: m.wolbers@maw.ru.nl 


\section{Appendix}

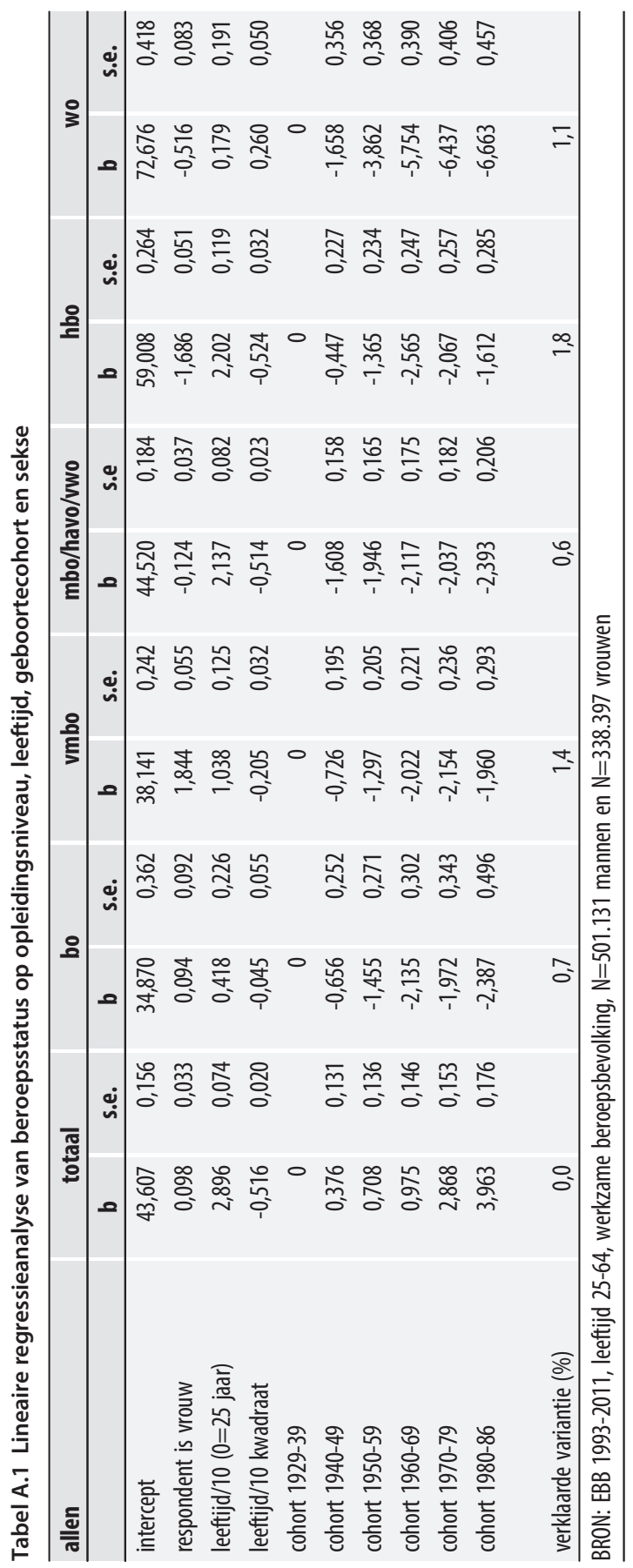


MENS \& MAATSCHAPPIJ

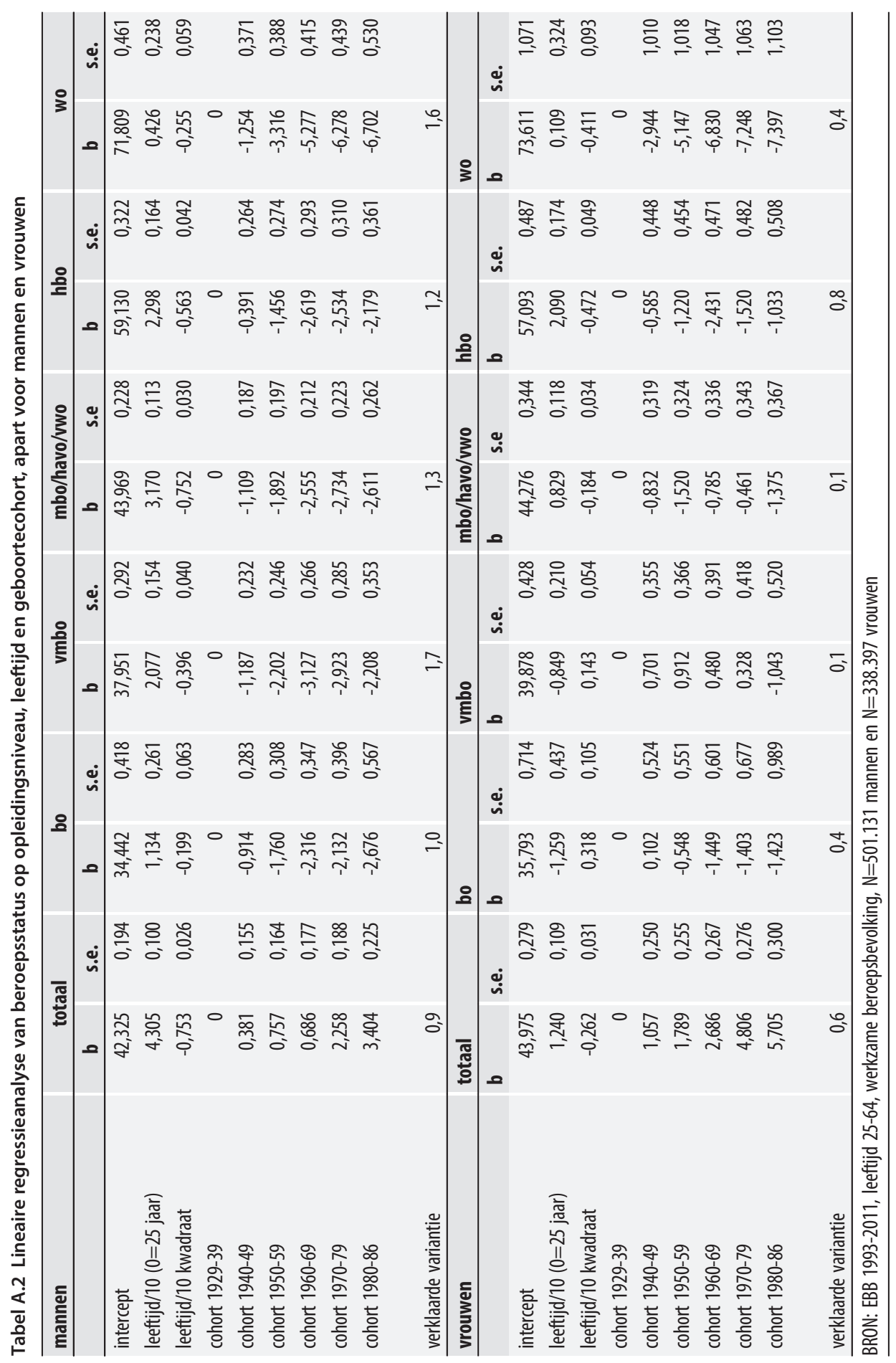

